\title{
Efficacy of entomopathogenic nematodes against the cabbage butterfly (Pieris brassicae (L.) (Lepidoptera: Pieridae) infesting cabbage under field conditions
}

Tarique Hassan Askary ${ }^{1 *}$ and Mohammad Jamal Ahmad²

\begin{abstract}
Experiments were conducted to test the pathogenicity of entomopathogenic nematode, Heterorhabditis pakistanensis alone and in combination with the chemical insecticides, viz., Dichlorvos and Quinalphos and Neem product, viz., Azadirachtin against the cabbage butterfly, Pieris brassicae (L.) (Lepidoptera: Pieridae) infesting cabbage plants under laboratory and field conditions. In laboratory test, inoculum level of 200 infective juveniles (IJs) was most effective causing mortality to both $3 \mathrm{rd}$ and 4 th instars larvae at $48 \mathrm{~h}$. Nematode multiplication rate in insect cadaver was inversely proportional to the size of initial inoculum level of IJs, whereas IJs yield was directly proportional to the size of larva. The 4th instar larva resulted in a highest yield of IJs, followed by 3rd, 2nd, and 1st instars larvae at all the inoculum levels used in the study. IJs were found compatible with the chemical insecticides and Neem product at lower than half of the optimum single dose. The cumulative mean survival percentage of IJs recorded the highest (77.5\%) in the combination of $100 \mathrm{IJs}+$ Azadirachtin (0.25\%) and lowest (70.6\%) in $100 \mathrm{lJs}+$ Dichlorvos 76 EC (0.05\%). Under field conditions, H. pakistanensis $\left(3.0 \mathrm{lakh} \mathrm{lJs} / \mathrm{m}^{2}\right)+$ Dichlorvos 76 EC $(0.025 \%)$ resulted to the highest larval mortality (79.65\%), followed by H. pakistanensis (3.0 lakh IJs/ $\left.\mathrm{m}^{2}\right)+$ Azadirachtin (0.25\%), where it was $76.22 \%$. The larval mortality was the least (61.16\%) in case of $\mathrm{H}$. pakistanensis $\left(3.0 \mathrm{lakh} \mathrm{IJ} / \mathrm{m}^{2}\right)$ when applied alone. H. pakistanensis + Dichlorvos resulted to the highest increase (31.42\%) in cabbage yield over untreated control.
\end{abstract}

Keywords: Cabbage, Pieris brassicae, Entomopathogenic nematodes, Insecticides, Neem

\section{Background}

Cabbage (Brassica oleraceae L. var. capitata) is an important vegetable crop grown in almost all parts of India. Cabbage butterfly, Pieris brassicae (L.) (Lepidoptera: Pieridae), is one of the major limiting factors of cabbage production in Kashmir valley, causing severe losses to the crop by larval feeding on leaves. Young larvae scrap the leaf surface whereas older larvae consume leaves from the margins inward leaving only the main veins. In

\footnotetext{
*Correspondence: tariq_askary@rediffmail.com

'Division of Entomology, Faculty of Agriculture, Sher-e-Kashmir University of Agricultural Sciences and Technology, Wadura Campus, Sopore, Jammu and Kashmir 193201, India

Full list of author information is available at the end of the article
}

case of heavy infestation, the entire plants are eaten up. Since past few decades, chemical insecticides have been a general practice used by cabbage growers for the management of $P$. brassicae in Kashmir valley. But the adverse effect of chemicals on the environment such as ground water contamination, pesticide resistance, toxicity hazards, and destruction of biodiversity of useful natural enemies demand an effective alternative method of crop insect pest management that should be ecofriendly and safe for non-target organisms. Entomopathogenic nematodes (EPNs) that belong to families, Steinernematidae and Heterorhabditidae, are lethal parasites of insect pests, safe to humans, other vertebrates, 
non-target organisms, easy to apply, and cause no hazardous effect on the environment (Askary and AbdElgawad 2017). Besides, they are compatible with many chemical insecticides (Gupta 2003; Priya and Subramanian 2008; Laznik and Trdan 2014) and Neem (Azadirachta indica) products (Pezowicz et al. 1997; Mahmoud 2007) at lower doses and short-term exposures. Therefore, can be tank mixed for applying together in the field against target crop insect pests.

Keeping in view the role of EPNs in managing the insect pests, the present study was undertaken for the first time in Kashmir valley by using nematodes in combination with chemical insecticides, viz., Dichlorvos 76 EC (Emulsified Concentrate), Quinalphos 25 EC, and Neem product, viz., Azadirachtin against the target pest cabbage butterfly under field conditions.

\section{Materials and methods}

\section{Rearing of rice moth, Corcyra cephalonica}

In order to multiply EPNs, the rice moth, Corcyra cephalonica Stainton (Lepidoptera: Pyralidae) was used as a host. The insect was reared on artificial diet under controlled atmospheric conditions at Biological Control Laboratory of the Division of Entomology, Sher-eKashmir University of Agricultural Sciences and Technology of Kashmir (SKUAST-K), Shalimar campus, Srinagar. Maize was used as artificial diet to rear $C$. cephalonica. The crushed maize grain was sterilized in an oven at $100{ }^{\circ} \mathrm{C}$ for $30 \mathrm{~min}$. Two kilograms of the sterilized crushed maize was filled in a wooden box $(15 \times 30$ $\times 45 \mathrm{~cm}$ ) and 2000 eggs of C. cephalonica obtained from Biological Control Laboratory were spread on the crushed maize kept in the wooden box. The box was fitted with perforated lid. The larvae were ready for use after 45 days. Some of $C$. cephalonica larvae were left in the box to complete their life cycle and for the emergence of rice moths. Adults were collected and transferred to separate oviposition containers for egg laying. The eggs thus were collected from oviposition containers were added fresh on an artificial diet prepared according to Patel (2011).

\section{Preparation of entomopathogenic nematode culture}

EPN Heterorhabditis pakistanensis used in the study was obtained from its clay powder formulation supplied by National Bureau of Agricultural Insect Resources (NBAIR), Bengaluru, India. It was maintained in the laboratory at Division of Entomology, SKUAST-K, Shalimar campus, Srinagar, India. The nematode was cultured in the last instar larvae of C. cephalonica. Hundred larvae were kept in $50 \mathrm{~cm}$ diameter Petri dish, lined with a filter paper, and inoculated with approximately 10,000 infective juveniles (IJs) of $H$. pakistanensis contained in $1 \mathrm{ml}$ of sterilized distilled water. The Petri dishes were placed in Bio-oxygen demand (BOD) incubator at $20^{\circ} \mathrm{C}$ (Dutky et al. 1964). After incubation at $20^{\circ} \mathrm{C}$ for 3 days, the infected C. cephalonica larvae were taken out from the Petri dishes and the cadavers were placed on white traps (White 1927). White trap was placed in BOD incubator at $20^{\circ} \mathrm{C}$. After 7-10 days, IJs moved from the $C$. cephalonica cadavers to the water reservoir of white trap. IJs were collected in a clean beaker, allowed to settle for $1 \mathrm{~h}$, and the supernatant was decanted. The beaker was refilled by distilled water, and the process was repeated 3 times until a clean suspension was obtained.

\section{Storage of the entomopathogenic nematode}

The IJs collected were washed with $0.05 \%$ formaldehyde and stored in the sterile distilled water in tissue culture flasks in BOD at $10^{\circ} \mathrm{C}$. The nematode concentration was kept in the range of $10,000 \mathrm{IJs} / \mathrm{ml}$ of sterile distilled water. IJs were acclimatized at room temperature (22$25^{\circ} \mathrm{C}$ ) for an hour before use.

\section{Maintenance of cabbage butterfly in laboratory}

Larvae of the cabbage butterfly, P. brassicae, were collected from the cabbage growing fields at SKUAST-K, Srinagar. The larvae were brought to the laboratory, placed in rearing cages $(20 \mathrm{~cm} \times 12 \mathrm{~cm})$ and maintained at room temperature. Fresh unsprayed leaves of cabbage were collected from the field for the rearing of larvae. The feed was changed at every $24 \mathrm{~h}$ and the cages were simultaneously cleaned thoroughly to prevent any contamination. The neonate larvae were allowed to develop by feeding on the cabbage leaves until they reach the full grown. The appropriate instar of $P$. brassicae was harvested and placed in sterilized plastic containers with a mesh for ventilation ready to be used in the bioassay. Dead $P$. brassicae larvae were removed from the rearing cage daily and the fecal pellets were cleaned with moist cotton wool.

\section{Laboratory test of entomopathogenic nematode against cabbage butterfly}

IJs of $H$. pakistanensis were evaluated against the larvae of $P$. brassicae but prior to the evaluation viability of the IJs were ascertained after examining them under a stereoscopic microscope. Only live and active IJs were considered for the experiment. Four different concentrations (50, 100, 150, and 200) of IJs/200 $\mu \mathrm{l}$ of distilled water were prepared. Bioassay was performed in 6-well plates. Each well was lined by a Whatman no. 1 filter paper. One surface sterilized $P$. brassicae was placed in each well of a single 6-well plate and required concentration of IJs was added into each well. For each instar larva of $P$. brassicae, one single 6-well plate was used. Thus, each treatment was replicated 6 times. After 
placing the larva and adding IJs into it, the 6-well plates were covered by their respective lids, labeled and incubated into BOD at $20 \pm 2{ }^{\circ} \mathrm{C}$. While incubating, the 6 well plates were kept in plastic bags to conserve moisture. The plates were observed regularly upto 4 days for the mortality of $P$. brassicae larvae. The infected larvae were lightly rinsed in sterilized distill water and placed on a white trap for the emergence of IJs.

\section{Compatibility test}

This experiment was carried out to assess the survival ability of EPN, H. pakistanensis in combination with insecticides/neem product. Two chemical insecticides, viz., Dichlorvos 76 EC and Quinalphos 25 EC and one neem (Azadirachta indica) product, viz., Azadirachtin 50,000 ppm were used in the study. One hundred IJs were kept in combinations at 3 different concentrations of Dichlorvos 76 EC, Quinalphos 25 EC, and Azadirachtin 50,000 ppm, i.e., one at recommended concentration and 2 at lower than recommended concentrations. For each combination of IJs + insecticide/neem product, single 6-well plate was used. The percentage survival and mortality of IJs were assessed at 24,48 , and $72 \mathrm{~h}$ interval.

\section{Field efficacy of entomopathogenic nematode against cabbage butterfly}

The efficacy of $H$. pakistanensis was tested under field conditions against P. brassicae during 2017-2018 season. Cabbage cv. Golden Acre seedlings were obtained from vegetable nursery of SKUAST-K. Seedlings were 28 days old, and were transplanted at a farmer's field located at Ganderbal, Kashmir. The experiment was laid out with 5 treatments and 4 replications, following randomized block design (RBD). The size of each plot was $4 \mathrm{~m}^{2}(2 \times$ $2 \mathrm{~m})$. Spacing was maintained $(45 \mathrm{~cm} \times 45 \mathrm{~cm})$ among the rows and plants. Treatments were applied by the onset of insect incidence with the help of watering can provided with a nozzle having small holes to break up the stream of water into small droplets. The field temperature in the morning hours during nematode application was $22 \pm 2{ }^{\circ} \mathrm{C}$. The percentage of mortality of insect larvae was recorded at 24, 48, and $72 \mathrm{~h}$. The dead insect larvae (cadavers) were collected on daily basis in order to check the pathogenicity of the cadavers by placing them on a white trap for the release of IJs.

\section{Statistical analysis}

Statistical analysis was performed by the SPSS (version 16.0) statistical software package. The percentage of insect mortality data were analyzed by multifactor ANOVA and means of all experiments were used to compare the efficacy of treatments $(P<0.05)$.

\section{Results and discussion Laboratory tests}

Larval mortality was found negatively correlated with increase of IJs inoculum level of $H$. pakistanensis. In case of $50 \mathrm{IJs}$ inoculum level, the mortality recorded at 45 and $48 \mathrm{~h}$ for 1 st and 2 nd instar larvae of $P$. brassicae, respectively, whereas inoculum level of 150 and 200 IJs were at par causing mortality at $24 \mathrm{~h}$ to 1 st and 2 nd instar larvae (Table 1).

Inoculum level of 200 IJs was the most effective rate that caused mortality to both 3rd and 4th instars larvae at $48 \mathrm{~h}$. However, 50 and 100 IJs consumed maximum time causing mortality to 3rd instar larvae at $70 \mathrm{~h}$ and 4th instar larvae at 91 and $95 \mathrm{~h}$, respectively. Thus, increase in inoculum level of IJs resulted in high larval mortality of $P$. brassicae at quicker rate than at lower inoculum level. It was also observed that the time consumed by IJs to kill the larva depends upon the size of the larva. At a given inoculum level, the 2nd and 3rd instar larvae were killed at a short interval of time than the 4th instar. Obtained results confirm the findings of Mantoo and Zaki (2014) who observed that with the increase in inoculum level of IJs, time consumed for larval mortality decreased but when the larval size increased the time consumed in larval mortality also increased. Similar findings were also reported by other research workers (Lalramliana 2009; Gorgadze et al. 2018).

\section{Nematode production in larvae of cabbage butterfly}

The nematode production was significantly affected by the size of $P$. brassicae larvae. The multiplication of nematode in different instars of insect cadavers at one particular inoculum level was significantly different $(P \leq$ $0.05)$ from each other. The maximum emergence of IJs was recorded from 4th instar larva, followed by 3rd, 2nd, and 1st instars larvae (Fig. 1).

Nematode multiplication rate in insect cadaver was inversely proportional to the size of initial inoculum level of IJs. The multiplication rate was maximum by inoculum level of 50, followed by 100,150 and 200 IJs. In case of 1st instar cadaver, the production of IJs was maximum $(18,340)$ at $50 \mathrm{IJs}$ and minimum $(12,665)$ at 100 IJs inoculum level and both were significantly different $(P \leq 0.05)$ from each other; however, there were not much difference in IJs production between inoculum level of 100 and 150 IJs and statistically not different from each other. IJs recovered from 3rd instar cadaver was maximum $(1,05,328)$ with inoculum level of $50 \mathrm{IJs}$, followed by 100 IJs $(98,180), 150$ IJs $(94,375)$ and 200 IJs $(81,140)$ and they were significantly different $(P \leq$ 0.05 ) from each other. Similarly, IJs recovered from 4th instar cadaver was maximum by 50 IJs $(1,61,672)$, followed by 100 IJs $(1,40,118), 150$ IJs $(1,38,466)$, and 
Table 1 Correlation between different concentration of infective juveniles $\left(\mathrm{IJ}_{\mathrm{S}}\right)$ of Heterorhabditis pakistanensis and period of larval mortality of different instars of Pieris brassicae under laboratory conditions

\begin{tabular}{|c|c|c|c|c|}
\hline \multirow{2}{*}{$\begin{array}{l}\text { Number } \\
\text { of IJs/ } \\
\text { larva }\end{array}$} & \multicolumn{4}{|c|}{ 100\% larval mortality (h) } \\
\hline & 1st instar larva & 2nd instar larva & 3rd instar larva & 4th instar larva \\
\hline 50 & 45 & 48 & 70 & 95 \\
\hline 100 & 41 & 44 & 70 & 91 \\
\hline 150 & 24 & 24 & 66 & 70 \\
\hline 200 & 24 & 24 & 48 & 48 \\
\hline$r=$ & $-0.92^{*}$ & $-0.93^{*}$ & $-0.86^{*}$ & $-0.96^{*}$ \\
\hline
\end{tabular}

200 IJs $(1,27,645)$ and they were statistically different from each other.

Thus, overall results indicated that nematode reproduction rate inside the insect cadaver was inversely proportional to the size of nematode initial inoculum level but directly proportional to the size of insect larva. The reproduction rate of nematode at lowest initial inoculum level was highest in an insect cadaver; however, progeny production increased with the increase in larval size. This confirms that when the food is plenty the reproduction capacity of nematode increases. Since the EPNs have a mutualistic association with its symbiotic bacteria, which lead to the conversion of insect host into a nutrient soup to which the nematodes feed (Askary 2010). Thus, the progeny production solely depends on the total nutrition available. In the large sized larvae, the total quantity of nutrient soup available for the nematodes is relatively more, which supports maximum production of nematodes and consequently no competition.
The findings confirm the report of Bulla Jr et al. (1975) that insect larvae in a later stage of bacterial infection are under greater nutritional stress than those in an earlier stage and that this may influence the production of nematode progeny. The increased production may be the result of bacterial infection initiating the breakdown of complex food storage molecules, allowing quicker utilization by the nematode and thereby contributing to enhanced nematode development (Mantoo 2011).

\section{Compatibility of nematode with chemical insecticides/ neem product}

The cumulative mean of highest survival percentage of IJs after $72 \mathrm{~h}$ was noticed at the combination of $100 \mathrm{IJs}+$ Azadirachtin @ 0.125\% (81.8\%), followed by 100 IJs + Quinalphos 25 EC @ 0.0175\% (80.9\%), and 100 IJs + Dichlorvos 76 EC @ 0.025\% (80.3\%) (Table 2).

The cumulative mean of least survival percentage of IJs after $72 \mathrm{~h}$ was observed at $100 \mathrm{IJs}+$ Dichlorvos $76 \mathrm{EC}$

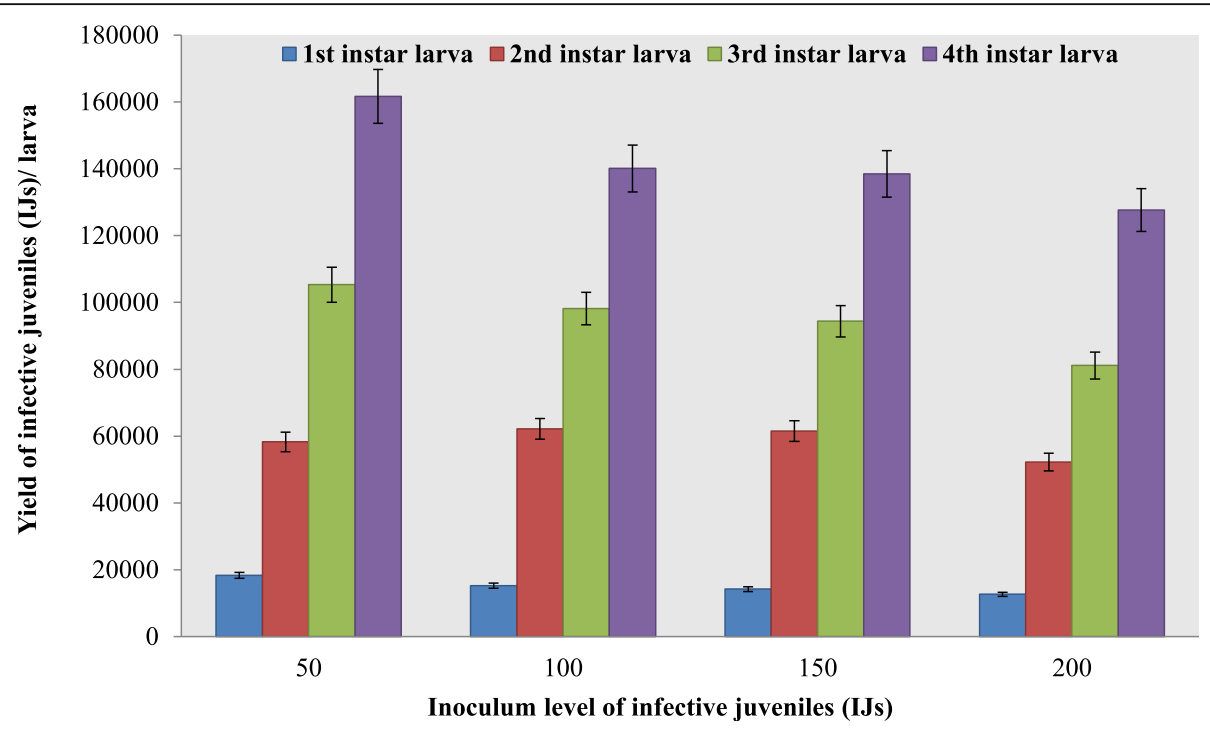

Fig. 1 Average yield of Heterorhabditis pakistanensis obtained from the cadavers of cabbage butterfly Pieris brassicae at different inoculums level under laboratory conditions 
Table 2 Compatibility of infective juveniles (IJs) of Heterorhabditis pakistanensis with different insecticides and neem product under laboratory conditions

\begin{tabular}{|c|c|c|c|c|c|}
\hline \multirow[t]{2}{*}{ Treatments } & \multicolumn{3}{|c|}{ Mean mortality (\%) of IJs at different intervals (h) } & \multicolumn{2}{|c|}{ Cumulative mean } \\
\hline & 24 & 48 & 72 & $\%$ IJs mortality & \% IJs survival \\
\hline 100 IJs + Quinalphos 25 EC @ 0.0175\% & $14.8(21.1)^{*}$ & $20.5(26.8)$ & $22.0(27.8)$ & 19.1 & 80.9 \\
\hline 100 IJs + Quinalphos 25 EC @ 0.035\% & $18.5(25.4)$ & $25.1(30.0)$ & $29.3(32.7)$ & 24.3 & 75.7 \\
\hline 100 IJs + Quinalphos 25 EC @ 0.07\% & $30.0(33.1)$ & $40.3(39.3)$ & $47.6(43.6)$ & 39.3 & 60.7 \\
\hline 100 IJs + Dichlorvos 76 EC @ 0.025\% & $15.0(22.7)$ & $20.8(27.0)$ & $23.3(28.7)$ & 19.7 & 80.3 \\
\hline 100 IJs + Dichlorvos 76 EC @ 0.05\% & $20.1(26.5)$ & $31.0(33.7)$ & $37.1(37.5)$ & 29.4 & 70.6 \\
\hline 100 IJs + Dichlorvos 76 EC @ 0.1\% & $34.8(36.1)$ & $50.3(45.1)$ & $61.1(50.9)$ & 48.7 & 51.3 \\
\hline 100 IJs + Azadirachtin @ 0.125\% & $14.5(22.3)$ & $19.3(26.0)$ & $21.0(27.1)$ & 18.2 & 81.8 \\
\hline 100 IJs + Azadirachtin @ 0.25\% & $16.3(23.7)$ & $23.6(29.0)$ & $27.8(31.7)$ & 22.5 & 77.5 \\
\hline 100 IJs + Azadirachtin @ 0.5\% & $28.5(32.1)$ & $37.0(37.4)$ & $42.3(40.5)$ & 35.9 & 64.1 \\
\hline Untreated control (100 IJs only) & $4.1(11.6)$ & $4.1(11.6)$ & $4.1(11.6)$ & 4.1 & 95.9 \\
\hline
\end{tabular}

$\mathrm{CD}(P \leq 0.05)$ : Treatment: 1.73; Duration: 0.94; Treatment $\times$ Duration: 2.99: Design: CRD; Replication: six

*Figures in parenthesis are Arc sine transformed value of mean percent mortality

@ 0.1\% (51.3\%), followed by 100 IJs + Quinalphos 25 EC @ 0.07\% (60.7\%), and 100 IJs + Azadirachtin @ 0.5\% (64.1\%). The high survival percentage of IJs showed a high compatibility and this may be due to very less concentration of chemical insecticides/neem product and so caused least effect on nematodes, whereas the low survival percentage of IJs is an indication of incompatibility, which may be due to toxic effect of insecticide/neem product on nematodes. The combinations where the cumulative mean survival percentage of IJs was recorded around $70 \%$ were $100 \mathrm{IJs}+$ Azadirachtin @ 0.25\% (77.5\%), 100 IJs + Quinalphos 25 EC @ 0.035\% (75.7\%), and 100 IJs + Dichlorvos 76 EC @ 0.05\% (70.6\%), which indicates the compatibility of nematodes with chemical insecticides/neem product (Table 2). The findings agree with the report of several other workers that at lower doses and short term exposure, EPNs are compatible with quinalphos (Karunakar et al. 2002; Easwaramoorthy and Sankaranarayanan 2003), dichlorvos (Zhang et al. 1994), and Azadirachtin (Ali et al. 2006).
Field efficacy of nematode against cabbage butterfly H. pakistanensis (3.0 lakh $\left.\mathrm{IJs} / \mathrm{m}^{2}\right)+$ Dichlorvos $76 \mathrm{EC}$ $(0.025 \%)$ resulted to the highest larval mortality rates at 24,48 , and $72 \mathrm{~h}$, which was $69.36,77.20$, and $79.65 \%$, respectively, followed by $H$. pakistanensis (3.0 lakh IJs $/ \mathrm{m}^{2}$ ) + Azadirachtin @ 0.25\%, 66.17, 74.26, and 76.22\%, respectively, H. pakistanensis @ 3.0 lakh IJs $/ \mathrm{m}^{2}+$ Quinalphos 25 EC @ 0.035\%, 64.48, 73.36, and 74.53\%, respectively and the least with $H$. pakistanensis @ 3.0 lakh IJs $/ \mathrm{m}^{2}$ applied alone, where it was 52.42, 59.70, and $61.16 \%$, respectively (Table 3 ). Among the treatments, larval mortality rate at $24 \mathrm{~h}$ interval was significantly different $(P \leq 0.05)$ with the mortality resulted at $48 \mathrm{~h}$. However, at 48 and $72 \mathrm{~h}, \mathrm{H}$. pakistanensis (3.0 lakh IJs/ $\mathrm{m}^{2}$ ) + Azadirachtin @ 0.25\% and H. pakistanensis (3.0 lakh IJs $/ \mathrm{m}^{2}$ ) + Quinalphos $25 \mathrm{EC}$ were not significantly different from each other.

The results are similar to the findings of Le Vieux and Malan (2015) who reported synergistic effects between EPN, $H$. bacteriophora and chemical insecticide, imidacloprid and the combination significantly increased the

Table 3 Efficacy of Heterorhabditis pakistanensis alone and in combination with insecticides and neem product against Pieris brassicae infesting cabbage under field condition

\begin{tabular}{|c|c|c|c|}
\hline \multirow[t]{2}{*}{ Treatments } & \multicolumn{3}{|c|}{ Mean mortality (\%) of Pieris brassicae larvae at different intervals (h) } \\
\hline & 24 & 48 & 72 \\
\hline Heterorhabditis pakistanensis @ 3.0 lakh IJs/m² & 52.42 & 59.70 & 61.16 \\
\hline H.pakistanensis@3.0 lakh IJs/m².+Quinalphos 25 EC @ 0.035\% & 64.48 & 73.36 & 74.53 \\
\hline H.pakistanensis@3.0 lakh IJs/m²+Dichlorvos 76 EC @ 0.025\% & 69.36 & 77.20 & 79.65 \\
\hline H.pakistanensis@3.0 lakh IJs/m²+ Azadirachtin @ 0.25\% & 66.17 & 74.26 & 76.22 \\
\hline Untreated control & 3.30 & 4.0 & 4.0 \\
\hline
\end{tabular}


Table 4 Effect on yield of cabbage after application of Heterorhabditis pakistanensis alone and in combination with insecticides and neem product against Pieris brassicae infesting cabbage under field conditions

\begin{tabular}{llll}
\hline Treatments & $\begin{array}{l}\text { Yield of cabbage } \\
\left(\mathrm{q} / 4 \mathrm{~m}^{2} \text { plot }\right)\end{array}$ & $\begin{array}{l}\text { Yield of cabbage } \\
(\mathrm{q} / \mathrm{hec})\end{array}$ & $\begin{array}{l}\text { \% increase in yield over } \\
\text { untreated control }\end{array}$ \\
\hline $\begin{array}{l}\text { Heterorhabditis pakistanensis @ 3.0 lakh IJs } / \mathrm{m}^{2} \\
\text { H. pakistanensis @ 3.0 lakh IJs } / \mathrm{m}^{2}+\text { Quinalphos }\end{array}$ & 0.081 & 202.5 & 15.71 \\
$\begin{array}{l}\text { 25 EC @ 0.035\% } \\
\text { H. pakistanensis @ 3.0 lakh IJs } / \mathrm{m}^{2}+\text { Dichlorvos }\end{array}$ & 0.086 & 215.0 & 22.85 \\
76 EC @ 0.025\% & 0.092 & 230.0 & 31.42 \\
$\begin{array}{l}\text { H. pakistanensis @ 3.0 lakh IJs } / \mathrm{m}^{2}+\text { Azadirachtin } \\
\text { @ 0.25\% }\end{array}$ & 0.089 & 222.5 & 27.14 \\
Untreated control & & & 175.0 \\
CD $(P \leq 0.05)$ & 0.070 & 7.37 & \\
\hline
\end{tabular}

pathogenicity of $H$. bacteriophora against vine mealy bug, Planococcus ficus, in South African vineyards. Sabry et al. (2016) also reported that $S$. carpocapsae All in combination with the half recommended dose of chemical insecticides was much effective against tomato leaf miner, Tuta absoluta, than the nematode applied alone.

\section{Cabbage yield}

The yield of cabbage was recorded highest $(0.092 \mathrm{q}$ (quintal) $/ 4 \mathrm{~m}^{2}$ ) in the plot treated with $H$. pakistanensis (3.0 lakh IJs $\left./ \mathrm{m}^{2}\right)+$ Dichlorvos 76 EC $(0.025 \%)$ and it was significantly different $(P \leq 0.05)$ from the treatment $H$. pakistanensis@3.0 lakh IJs/m $/ \mathrm{m}^{2}+$ Quinalphos 25 EC @ $0.035 \%\left(0.086 \mathrm{q} / 4 \mathrm{~m}^{2}\right)$ and $H$. pakistanensis @ 3.0 lakh $\mathrm{IJs} / \mathrm{m}^{2}\left(0.081 \mathrm{q} / 4 \mathrm{~m}^{2}\right)$ used alone but not significantly different from $H$. pakistanensis (3.0 lakh IJs $/ \mathrm{m}^{2}$ ) + Azadirachtin@ 0.25\% (0.089 q/4 m²) (Table 4).

The percentage increase in cabbage yield/plot over untreated plot was highest (23.91\%) with the treatment with $H$. pakistanensis (3.0 lakh IJs/ $\left.\mathrm{m}^{2}\right)+$ Dichlorvos 76 EC $(0.025 \%)$ and it was closely followed by H. pakistanensis (3.0 lakh IJs $\left./ \mathrm{m}^{2}\right)+$ Azadirachtin @ 0.25\% (21.34\%), H. pakistanensis @ 3.0 lakh IJs/ m² + Quinalphos 25 EC @ 0.035\% (18.60\%), and H. pakistanensis @ 3.0 lakh IJs $/ \mathrm{m}^{2}$ alone (13.58\%) (Table 4). Similar results were found by Saba (2019) who prepared 3 combinations of EPNs and chemical insecticide, i.e., H. bacteriophora MK256378 + Imidacloprid $17.8 \mathrm{SL}, H$. bacteriophora MK256378 + Dimethoate $30 \mathrm{EC}$, and $H$. bacteriophora MK256378 + Chlorpyriphos 20 EC and applied against diamondback moth, Plutella xylostella, infesting cabbage in field. The results indicated significant higher mortality rates of insect larvae where nematode was applied in combination with chemical insecticides than where the nematode was applied alone.

\section{Conclusion}

The EPN, H. pakistanensis, appeared as a promising biocontrol agent against $P$. brassicae and exhibited good compatibility with the chemical insecticides. The combined applications of EPN + insecticides resulted in significant high larval mortality rates of $P$. brassicae and higher crop yield than the treatment with the nematode alone. Multi-locational field trials in farmers' fields should be conducted prior to the implementation of this IPM module.

\section{Abbreviations}

NBAIR: National Bureau of Agricultural Insect Resources; SKUAST-K: Sher-eKashmir University of Agricultural Sciences and Technology of Kashmir; EC: Emulsified concentrate; IJs: Infective juveniles; EPN: Entomopathogenic nematode; BOD: Bio-oxygen demand; RBD: Randomized block design

\section{Acknowledgements}

This study was supported by RCM-Division of Entomology project entitled "Nematode based integrated management of cabbage butterfly (Pieris brassicae) infesting cabbage and cauliflower" of SKUAST-K, India.

\section{Authors' contributions}

The first author, THA carried out the experiment and analyzed the data and was the major contributor. The second author, MJA reared the Corcyra cephalonica larvae for the multiplication of entomopathogenic nematodes and also made available the formulation of Heterorhabditis pakistanensis for the experiment. All authors read and approved the final manuscript.

\section{Authors' information \\ Tarique Hassan Askary is Assistant Professor and has specialization in nematology. M. Jamal Ahmad is Professor and Incharge, Biocontrol Laboratory at SKUAST-K, India.}

\section{Funding}

No funding from any source.

\section{Availability of data and materials}

All data generated or analyzed during this study are included in this article.

Ethics approval and consent to participate

Not applicable

\section{Consent for publication}

Not applicable

\section{Competing interests}

We, the authors do not have competing interests.

\section{Author details}

${ }^{1}$ Division of Entomology, Faculty of Agriculture, Sher-e-Kashmir University of Agricultural Sciences and Technology, Wadura Campus, Sopore, Jammu and 
Kashmir 193201, India. ${ }^{2}$ Division of Entomology, Faculty of Horticulture, Sher-e-Kashmir University of Agricultural Sciences and Technology, Shalimar, Srinagar, Jammu and Kashmir 190025, India.

Received: 18 September 2019 Accepted: 30 March 2020

Published online: 09 April 2020

\section{References}

Ali SS, Pervez R, Ahmad R, Hussain MA (2006) Compatibility of entomopathogenic nematodes with pesticides. PI Newsl 17:5

Askary TH (2010) Nematodes as biocontrol agents. In: Lichtfouse E (ed) Sociology, organic farming, climate change and soil science. Springer, The Netherlands, pp 347-378

Askary TH, Abd-Elgawad MMM (2017) Beneficial nematodes in agro-ecosystem: a global perspective. In: Abd-Elgawad MMM, Askary TH, Coupland J (eds) Biocontrol Agents: entomopathogenic and slug parasitic nematodes. CAB International, UK, pp 3-25

Bulla LA Jr, Rhodes RA, St Julian G (1975) Bacteria as insect pathogens. Ann Rev Microbiol 29:163-190

Dutky SR, Thompson JV, Cantwell GE (1964) A technique for the mass production of the DD-136 nematode. J Insec Path 6:417-422

Easwaramoorthy S, Sankaranarayanan C (2003) Biological control of sugarcane pests with entomopathogenic nematodes. In: Hussaini SS, Rabindra RJ, Nagesh M (eds) Current Status of Research on Entomopathogenic Nematodes in India. Project Directorate of Biological Control, India, pp 143-152

Gorgadze O, Bakhtadze G, Nebieridze D (2018) Efficacy of local entomopathogenic nematodes against Pieris brassicae $(L, 1758)$ (Lepidoptera: Pieridae). Int J Dev Res 8:23900-23903

Gupta PP (2003) Entomopathogenic nematodes-work done at Allahabad Agriculture Institute, Allahabad. In: Hussaini SS, Rabindra RJ, Nagesh M (eds) Current Status of Research on Entomopathogenic Nematodes in India. Project Directorate of Biological Control, India, pp 161-166

Karunakar G, Easwaramoorthy S, David H (2002) Compatibility of Steinernema feltiae, S. glaseri and Heterorhabditis indica with certain fertilizers, herbicides and pesticides. Sugar Tech 4:123-130

Lalramliana YAK (2009) Laboratory evaluation of the pathogenicity of three entomopathogenic nematodes against larvae of cabbage butterfly, Pieris brassicae Linnaeus (Lepidoptera: Pieridae). Sc Vis 9:166-173

Laznik Z, Trdan S (2014) The influence of insecticides on the viability of entomopathogenic nematodes (Rhabditida: Steinernematidae and Heterorhabditidae) under laboratory conditions. Pes Manag Sc 70:784-789

Le Vieux PD, Malan AP (2015) Prospects for using entomopathogenic nematodes to control the vine mealy bug, Planococcus ficus, in South African vineyards. S Africa J En and Vit 36:59-70

Mahmoud MF (2007) Combining the botanical insecticides NSK extract, Neem Azal T 5\%, Neemix 4.5\% and the entomopathogenic nematode Steinernema feltiae Cross N 33 to control the peach fruit fly, Bactrocera zonata (Saunders). P Prot Sc 43:19-25

Mantoo MA (2011) Isolation and evaluation of entomopathogenic nematodes for the biological control of important insect pests of crops in Kashmir. PhD Thesis, Division of Entomology, Sher-e-Kashmir University of Agricultural Sciences and Technology of Kashmir (SKUAST-K), Srinagar, India

Mantoo MA, Zaki FA (2014) Biological control of cabbage butterfly, Pieris brassicae by a locally isolated entomopathogenic nematode, Heterorhabditis bacteriophora SKUAST-EPN-Hr-1 in Kashmir. SKUAST J Res 16:66-70

Pezowicz E, Ignatowicz S, Kamionek M (1997) Comparative effects of water extracts of seeds of the Indian neem tree Azadirachta indica A. Juss, a plant derived insecticide, Neemix TM, and a synthetic insecticide, Bancol 50 WP. on the efficacy of the entomogenous nematode, Steinernema feltiae (Filip). Ann Warsaw Agril Univ SGGW, Horticulture 18:31-39

Priya P, Subramanian S (2008) Compatibility of entomopathogenic nematodes Heterorhabditis indica (Poinar, Karunakar and David) and Steinernema glaseri (Steiner) with insecticides. J Biol Cont 22:225-230

Patel RKM (2011) Comparative biology and mass production of Corcyra cephalonica (Stainton) (Pyralidae: Lepidoptera) on different food materials. PhD Thesis, Anand Agricultural University, Anand, India

Saba (2019) Management of diamondback moth (Plutella xylostella) infesting cabbage by using entomopathogenic nematodes. M.Sc. (Hort.) Thesis, Division of Entomology, Sher-e-Kashmir University of Agricultural Sciences and Technology of Kashmir (SKUAST-K), Srinagar, India
Sabry AH, Metwallya HM, Abolmaatyb SM (2016) Compatibility and efficacy of entomopathogenic nematode, Steinernema carpocapsae all alone and in combination with some insecticides against Tuta absoluta. Der Pharm Let 8: $311-315$

White GF (1927) A method for obtaining infective nematode larvae from cultures. Sc 66:302-303

Zhang L, Shono T, Yamanaka S, Tanabe H (1994) Effects of insecticides on the entomopathogenic nematode Steinernema carpocapsae Weiser. App Ent Zool 29:539-547

\section{Publisher's Note}

Springer Nature remains neutral with regard to jurisdictional claims in published maps and institutional affiliations.

\section{Submit your manuscript to a SpringerOpen ${ }^{\circ}$ journal and benefit from:}

- Convenient online submission

- Rigorous peer review

- Open access: articles freely available online

High visibility within the field

- Retaining the copyright to your article

Submit your next manuscript at $\boldsymbol{\nabla}$ springeropen.com 